\title{
Anatomical and Physiological Considerations in the 'Hip Rotators Test' Related to the Stomatognathic System. A Brief Commentary
}

\author{
Consideraciones Anatomofisiológicas en el "Test de Rotadores de Cadera" \\ Relacionado con el Sistema Estomatognático. Un Breve Comentario
}

Orlando Conde Vázquez \& Juan Antonio Suárez Quintanilla

CONDE, V. O. \& SUÁREZ, Q. J.A. Anatomical and physiological considerations in the 'hip rotators test' related to the stomatognathic system. A brief commentary. Int. J. Morphol., 38(2):363-366, 2020.

SUMMARY: Manual tests in clinical investigation must be supported by anatomical and physiological findings in order to obtain an objective information. The application of different mandibular positions in children obtains a variation in the 'hip rotators test' $(\mathrm{p}<0.001)$. The possible relationships behind the muscle tone of the external rotators of the hips and the stomatognathic system are exposed, with special attention on the fascial tissue and its morphological characteristics. Despite these anatomical and physiological connections, there is no further evidence of a strong cause-effect relationship in this test.

KEY WORDS: Muscle Tonus; Fascia; Stomatognathic System.

\section{INTRODUCTION}

The 'hip rotators test' as it was conceived by Autet (1985) is a manual maneuver to check the viscoelastic characteristics of the thigh posterolateral components. The test runs with the subject in a supine position, relaxed, with his/her arms along the body on the table and a neutral sight, with no cervical or ocular rotation. The clinician stands at the patient's feet, takes the heels of the subject placing his thumbs behind and below the peroneal malleolus, without plantar contact and passively carries the lower limbs towards the medial rotation. If one limb rotates less than the opposite, 'hypertonic' is noted; otherwise, the clinician notes an 'isotonic' response. It is a common test to check the muscular tone of lateral rotators muscles of the hips and its variations due to certain reflexes, habitually related to postural control exploration (Gagey \& Weber, 2001; Scheibel et al., 2017).

Some authors have described modifications in the results of the maneuver as a fact of modifying the occlusal contacts in some people (Mathurin, 2005; Conde Vázquez, 2019). Therefore, it was determined that in some way the variation in the stomatognathic system (SS) could have an impact on the viscoelastic properties of these muscles. Furthermore, these relationships are supported by clinical findings about the implications of occlusion in the human standing posture, normally explained through trigeminal inputs (Gangloff et al., 2000; Gangloff \& Perrin, 2002; Bracco et al., 2004), even in orthognathic surgery (PayaArgoud et al., 2019), enhancing the importance of the stomatognathic proprioceptive information on the central nervous system (CNS). Reviews on the subject do not clarify these kinds of connections whether it concerns occlusion (Michelotti et al., 2011) or temporomandibular disorders (Olivo et al., 2006; Rocha et al., 2013).

The interaction mode of dental occlusion on the test remains unclear. In this paper, we will expose the main ideas to support this relationship based on the current human anatomy and physiology, regarding previous work (Conde Vázquez).

\section{MATERIAL AND METHOD}

A pre-post intervention study was developed on 28 children aged between 6 and 14 years $(9.4 \pm 2.6)$. Thirteen of the children were male and 15 female. Inclusion criteria supposed to not carry any oral treatment at the moment of the study, be able to follow the orders of the operator, to not 
have any physical or psychological illness that could alter a priori the motor behavior, and the guardian/parent's acceptance and signature of the informed consent. The Declaration of Helsinki was respected.

The «hip rotators test» was performed 3 times, each of them with a different occlusal position: in mandibular resting position (T1), maximum intercuspation position (T2) and without dental contact through cotton rolls between the arcades (T3). Between each test, the children were instructed to stand up from the table and walk 4 or 5 steps.

Statistical treatment of data was performed with IBM SPSS software Version 21.0.

\section{RESULTS}

Table I shows descriptive data of the different 3 maneuvers. In this study, the majority of the subjects showed a right-hypertonic result in the initial test (T1), while it turns into isotonic response in the other mandibular conditions (T2 and T3).

For group comparisons before and after interventions, McNemar-Bowker and Cramér's V tests were performed. Table II shows the results, where significant changes between $\mathrm{T} 1$ and $\mathrm{T} 2$ response $\left(\chi^{2}=14.000 ; \mathrm{p}=0.001\right)$ are appreciated, but there is no significant relation between T2 and T3 $\left(\chi^{2}=\right.$ $1.000 ; \mathrm{p}=0.607)$. Cramér's V obtain a moderate degree of association between variables in $\mathrm{T} 1$ and $\mathrm{T} 2(\mathrm{~V}=0.458 ; \mathrm{p}=$ $0.019)$ and an intense relationship between $\mathrm{T} 2$ and $\mathrm{T} 3(\mathrm{~V}=$ $0.723 ; \mathrm{p}<0.001)$.

Table I. Cases number after hip rotators tests.

\begin{tabular}{cccc}
\hline & R-Hypertonic & L-Hypertonic & Isotonic \\
\hline $\mathrm{T}_{1}$ & 21 & 6 & 1 \\
$\mathrm{~T}_{2}$ & 11 & 2 & 15 \\
$\mathrm{~T}_{3}$ & 10 & 2 & 16 \\
\hline
\end{tabular}

$\mathrm{n}=28$; R: right; L: left.

Table II. McNemar-Bowker and Cramér's V values.

\begin{tabular}{lcc}
\hline & $\kappa^{2}$ & $V$ \\
\hline $\mathrm{T}_{1} / \mathrm{T}_{2}$ & $14.000^{* *}$ & $0.458^{*}$ \\
$\mathrm{~T}_{2} / \mathrm{T}_{3}$ & 1.000 & $0.723^{* *}$ \\
\hline$* \mathrm{p}<0.05$ & $* * \mathrm{p} \leq .0 .001$ &
\end{tabular}

\section{DISCUSSION}

Since the results suggest a relationship between the thigh posterolateral muscle tone and the SS, we support these findings based on the subsequent main hypotheses:
Via fascial interconnection: in recent years, the possible mechanisms underlying some types of pain and mechanical contribution to the human body have pointed directly to the fascial system (Wilke et al., 2018). Its structure and functionality could now be verified thanks to the knowledge of living tissues and the technology that made it possible. Thus, we observe the incredible architecture of human cells acting as 'tensegrity structures' due to the fascial ability to react under pressure, slip or tension, adapting the tissue to the demands with no impact on anatomy or physiology (Guimberteau et al., 2010). Indeed, studies have shown the microanatomy of the cell cytoskeleton and extra-cellular matrix composed by different biopolymers as actomyosin filaments, microtubules, and intermediate filaments, its behavior and implications for mechanotransduction, proliferation, and apoptosis of the cell (Ingber et al., 2014). This mechanical 'transmitting' capacity of the fascia is supported by the cytoskeleton and surrounding structures pre-stress system, which allows a rapid and long propagation of messages.

Based on this paradigm, the 'myofascial chain' concept and its clinical applications have been developed. It is based on the fascial interconnection at different levels and its continuity through distinct muscles or connective tissue (Myers, 2001; Klingler et al., 2014). Regarding the «hip rotators test» a 'deep frontal line' is described from flexor hallucis longus and flexor digitorum longus of the feet to the masseter and medial pterygoids muscles, passing through the deep posterior compartment of the leg, hip adductors, iliopsoas, diaphragm, mediastinal compartments, cervical prevertebral laminae, and hyoid muscles; although in the 'line' concept of the author (named meridian) the deep lateral rotators of the hip are not included, despite being arranged in the same fascial plane, due to dissimilar direction of muscle fibers (Myers). Studies have proved this tissue continuity in various myofascial chains, but not regarding this 'deep frontal line' (Wilke et al., 2016). Another author describes mandibular muscles being a part of the 'head' chain, but we do not know if he assumes continuity throughout the body to the lower limbs (Rosario, 2017).

Via CNS modulation: afferences from masticatory muscles, tooth pulp, and periodontal ligaments are driven to the mesencephalic nucleus of the trigeminus (MNT) by trigeminal nerves. From there, it connects with all the vestibular nuclei, the cerebellum and with spinal motor neurons. Through injection of wheat germ agglutinin coupled with horseradish peroxidase in the extraocular muscle of the cat, some authors observed sensory labeled neurons in the Gasser ganglion and the MNT, and transganglionic terminals in the pars interpolaris and 
caudalis of the spinal trigeminal nucleus, in the paratrigeminal nucleus, and the dorsal horn of the cervical spinal cord. Connections with the hypoglossal prepositus nucleus, nucleus of the solitary tract, cuneate nucleus and the superior colliculus have also been observed. All of these evoke a strong involvement of the trigeminal system in postural control and balance systems (Cuccia \& Caradonna, 2009). It seems important to us the connection with the reticular formation, which allows a linkage between autonomic impulses from CNS and SS supported in the discovery of intrafascial smooth muscle-like cells known as myofibroblasts (Schleip et al., 2005). Thus, the fascial system provides the ability to create a changing pre-tension state to adapt to environmental needs. This could cause an alteration in the muscle tone properties measured by the clinician in the 'hip rotators test' due to the impact on the musculoskeletal dynamics. Inversely, Ohlendorf et al. (2015) observed variations in jaw movement and position after hip total replacement, which they believe related to neuromuscular control, so CNS mediated.

Mixed model: another possibility remains in the multimodal function of fascia. On the one hand, myofibroblasts acting as smooth-like cells could be affected by SS afferences via the autonomic nervous system and by proprioceptive inputs transmitted by mechanoreceptors found in the connective tissue (mainly corpuscles of Ruffini and Vater-Pacini). On the other hand, mechanical strain, as well as the presence of stress-related cytokines, could generate myofibroblasts' contraction, and thanks of the mechanotransduction property of the fascial tissue, create a change in the muscle tone behavior. Both possibilities are not exclusive to each other.

\section{CONCLUSION}

The capabilities of fascial tissue are now being more deeply explored. Its histological structure suggests connections with the proprioceptive and autonomic nervous systems, and its continuity throughout the body allows that and mechanical demands could arrive remotely from the stimulated point. However, this myofascial chain from masticatory muscles to posterolateral thigh muscles has never been anatomically confirmed, although some authors suggest it (Myers; Rosário). Regarding possible with the CNS, although present, cannot solely explain a cause-effect relationship, since other inputs that may come into play during the test could alter the results due to the complex physiology of the CNS. More studies are necessary to isolate this information and obtain clear connections between the muscle tone of the hip rotators and the SS.
CONDE, V. O. \& SUÁREZ, Q. J. A. Consideraciones anatomofisiológicas en el "test de rotadores de cadera" relacionado con el sistema estomatognático. Un Breve Comentario. Int. J. Morphol., 38(2):363-366, 2020.

RESUMEN: Las pruebas manuales en la investigación clínica deben estar respaldadas por hallazgos anatómicos y fisiológicos para obtener una información objetiva. La aplicación de diferentes posiciones mandibulares en niños muestra una variación en la "prueba de rotadores de cadera" ( $\mathrm{p}<0,001)$. Se exponen las posibles relaciones del tono muscular de los rotadores externos de las caderas y el sistema estomatognático, con especial atención en el tejido fascial y sus características morfológicas. A pesar de estas conexiones anatomofisiológicas, no existe una evidencia mayor de una relación importante causa-efecto en esta prueba.

PALABRAS CLAVE: Tonus muscular; Fascia; Sistema estomatognático.

\section{REFERENCES}

Autet, B. Examen Ostéopathique Prenant en Compte L'Activité Tonique Posturale. Montpellier, Mémoire de la Sereto, 1985.

Bracco, P.; Deregibus, A. \& Piscetta, R.; Effects of different jaw relations on postural stability in human subjects. Neurosci. Lett., 356(3):22830, 2004.

Conde Vázquez, O. Étude des influences mandibulaires sur le test des rotateurs de hanche chez l'enfant. Neurophysiol. Clin., 49(3):254, 2019.

Cuccia, A. \& Caradonna, C. The relationship between the stomatognathic system and body posture. Clinics (São Paulo), 64(1):61-6, 2009.

Gagey, P. \& Weber, B. Posturología. Regulación y Alteraciones de la Bipedestación. 2 ${ }^{\mathrm{a}}$ ed. Barcelona, Masson, 2001.

Gangloff, P. \& Perrin, P. P. Unilateral trigeminal anaesthesia modifies postural control in human subjects. Neurosci. Lett., 330(2):179-82, 2002.

Gangloff, P.; Louis, J. P. \& Perrin, P. P. Dental occlusion modifies gaze and posture stabilization in human subjects. Neurosci. Lett., 293(3):203-6, 2000.

Guimberteau, J. C.; Delage, J. P.; McGrouther, D. A. \& Wong, J. K. F. The microvacuolar system: how connective tissue sliding works. J. Hand Surg. Eur. Vol., 35(8):614-22, 2010.

Ingber, D. E.; Wang, N. \& Stamenovic, D. Tensegrity, cellular biophysics, and the mechanics of living systems. Rep. Prog. Phys., 77(4):046603, 2014.

Klingler, W.; Velders, M.; Hoppe, K.; Pedro, M. \& Schleip, R. Clinical relevance of fascial tissue and dysfunctions. Curr. Pain Headache Rep., 18(8):439, 2014.

Mathurin, B. Le Test des Rotateurs: Recherche de L'Asymétrie Tonique Segmentaire. In: Lacour, M.; Weber, B.; Asseman, F. \& Barlaud, P. (Eds.). Posture et équilibre. Bipédie, Contrôle Postural et Représentation Corticale: Actualités de la Recherche Fondamentale, Enseignements de la Recherche Clinique et Applications. Marseille, Solal, 2005.

Michelotti, A.; Buonocore, G.; Manzo, P.; Pellegrino, G. \& Farella, M. Dental occlusion and posture: an overview. Prog. Orthod., 12(1):538, 2011.

Myers, T. Anatomy Trains: Myofascial Meridians for Manual and Movement Therapists. Edinburgh, Churchill Livingstone, 2001.

Ohlendorf, D.; Lehmann, C.; Heil, D.; Hörzer, S. \& Kopp, S. The impact of a total hip replacement on jaw position, upper body posture and body sway. Cranio, 33(2):107-14, 2015. 
Olivo, S. A.; Bravo, J.; Magee, D. J.; Thie, N. M. R.; Major, P. W. \& Flores-Mir, C. The association between head and cervical posture and temporomandibular disorders: a systematic review. J. Orofac. Pain, 20(1):9-23, 2006.

Paya-Argoud, M.; Tardieu, C.; Cheynet, F.; Raskin, A. \& Borel, L. Impact of orthognathic surgery on the body posture. Gait Posture, 67:25-30, 2019.

Rocha, C. P.; Croci, C. S. \& Caria, P. H. F. Is there relationship between temporomandibular disorders and head and cervical posture? A systematic review. J. Oral Rehabil., 40(11):875-81, 2013.

Rosário, J. L. Understanding muscular chains - A review for clinical application of chain stretching exercises aimed to correct posture. EC Orthop., 5(6):209-34, 2017.

Scheibel, A.; Zamfirescu, F.; Gagey, P. M.; Villeneuve, P. \& Weber, B. Pratiques de la Posturologie. Issy-les-Moulineaux, Elsevier Masson, 2017.

Schleip, R.; Klingler, W. \& Lehmann-Horn, F. Active fascial contractility: fascia may be able to contract in a smooth muscle-like manner and thereby influence musculoskeletal dynamics. Med. Hypotheses, 65(2):273-7, 2005.

Wilke, J.; Krause, F.; Vogt, L. \& Banzer, W. What Is evidence-based about myofascial chains: a systematic review. Arch. Phys. Med. Rehabil., 97(3):454-61, 2016

Wilke, J.; Schleip, R.; Yucesoy, C. A. \& Banzer, W. Not merely a protective packing organ? A review of fascia and its force transmission capacity. J. Appl. Physiol., 124(1):234-44, 2018.
Corresponding author:

Orlando Conde Vázquez.

Travesía del Restollal, 1-A, bajo

CP: 15702

Santiago de Compostela

La Coruña

ESPAÑA

Email: orlando.conde@rai.usc.es

Received: 29-07-2019

Accepted: 03-10-2019 